\author{
Frederick D. Drake \\ Dwight (IL) High School
}

In contemporary times the supposedly objective or scientific approach to the teaching of history, largely the result of nineteenth-century historian Leopold von Ranke's influence, has been challenged successful ly by an interpretation-centered, or relativistic, concept of history. Most historians acknowledge that to know the facts and documentary evidence, which are important, does not alone make history meaningful; the historian plays a major role in the reconstruction of history. Using knowledge of the present, the historian asks significant questions about the past. And it is the historian, enveloped in present time, who breathes meaning into the dead facts of the past by selection and interpretation.

The relativist view of history has important implications for the teaching of history. History educators, in addition to teaching factual information, have pursued the goal of helping students learn to think historically. This goal, which goes far beyond the imparting of knowledge and information to students, has become most urgent. The "knowledge explosion" has made the acquisition of important information overwhelming. knowing how to conduct research, weigh evidence judiciously, and render conclusions is a needed skill. Many history teachers, realizing that the quantity of knowledge has become more readily available and that it can appear to be unmanageable, overpowering, and insurmountable, have responded by incorporating the teaching of historical methods and historiography as a pedagogical technique. By helping students become aware of the historiographic aspect of history, it is hoped students will come to know four broad, organizing categories in the discipline of history. These include the nature of evidence, the necessity to define terms, the importance of interpretation in historical writings, and the role of personal values when significant meaning is imparted to facts. ${ }^{3}$ Awareness of these fundamental elements of history will help students learn to analyze and interpret the enormous amount of raw data now available in computer banks and libraries and that dispensed by the print media.

Most educational 1 iterature praises the use of primary source documents and the study of historiography as instructional procedures and regards the teaching of how an historian engages in the craft of history (methodology) as valuable in and of itself. According to Paul Cappuzzello and Mark Schlesinger in their bibliographical work Recent Trends in History Curricula and Pedagogy, many instructors "view history as a vehic $\overline{l e}$ to teach students how to Tearn." 4 During an ERIC (Educational Resources Information Center) search, I found numerous educators suggesting that students can profit immeasurably when introduced to historiography and given experience in the actual examination of primary sources. ${ }^{5}$ Students will not only comprehend more about the past, they will al so enjoy history more. It al so has been suggested that students will widen their imaginative capacities when they encounter the diverse interpretations of historians. Exposure to the raw materials of history likewise will help students to think in a logical and organized manner. Moreover, by becoming aware of the subjective element in historical interpretation, students become more aware of theilr own personal prejudices and value systems, and how these influence their own political outlook.

Accepting these studies that students benefit from being introduced to historiography, particulariy the nature of historical interpretation, the purpose of my research was to investigate empirically when and how such a 
teaching strategy should be employed. Making use of various aspects of the historical method as a learning tool imposes obstacles that must be overcome to be truly effective. From examination of research 1 iterature and observations of historians certain caveats become evident. First, students who are neophytes in the study of history tend to accept historical truth as some fixed or immutable past and the written reconstruction of the past by any one historian as the final and definitive version of what took place. Second, if students are indiscriminately or carelessly introduced to the subjective and realistic aspects of history, they may go to the other extreme and come to regard al1 written history as argumentative prose ajmed at some polemic point of view or furthering purely political objectives. 6

The dilemma to be resolved is how to teach the concept of valid historical interpretation without inculcating the notion that history is merely a collection of pretentious opinions or propagandistic assertions without any substantive basis. A warning of the deleterious effects of introducing students haphazardly to interpretive readings of a controversial and contradictory nature is summarized succinctly by William J. McGill in "History as Interpretation and as Argument." To correct initial misconceptions students may have regarding the relationship between primary sources and the historian's interpretation, MCGill urges that students receive a sound grounding in the historical method--but in a manner geared to prevent further misunderstanding. Thus he suggests use of a five-step pedagogical sequence: (1) answering a set of probing questions about an historical event from primary sources; (2) formulating a thesis on the basis of the documentary evidence; (3) ascertaining exactly what procedures were used to arrive at conclusions; (4) introducing new evidence to force students to reconsider their initial thesis and ultimate conclusions; and (5) presenting a series of readings that offer varied and differing interpretations by professional historians on the same subject dealt with by the students.

This teaching model prepares students for the variations, of ten contradictory, in historical interpretations by revealing to them the process whereby they are derived. It offers them an intellectual rationale for explaining and understanding why historians, using divergent source material, may arrive at differing conclusions. The insight thus gained allows them to differentiate between mere argumentation and opinion from logically reasoned deductions based on historical evidence. Exposing students to this historiographic fact of 1 ife is necessary to enlighten them as to the real nature of history, but it can and should be done without causing them undue confusion or undermining the credibility of all history.

Convinced that students must become aware of the intricacies of the historian's craft to really understand history, my research project was devised to achieve such exposure while seeking to avoid misconceptions. It was based on the assumption that when students comprehend the revisionist nature of history and perceive the methodology employed in reconstructing the past, they will be able to discern between opinionated polemics and valid historical interpretation based upon sound canons of scholarship. Cold War historiography is particularly well suited for this experiment, since it encompasses several schools of interpretation that present vastly different explanations (causative factors) and conclusions regarding postWorld War II confrontation between the United States (representing the Free Wor 1d) and the Soviet Union (representing the Communist B 1oc). Involved also are various ramifications of ideology, presentism, and the introduction of new evidence. The teaching strategy was structured to achieve the basic goal of really understanding the underlying concepts of history while, at 
the same time, eliminating the adverse effects resulting from an il1conceived approach.

\section{Introduction to $\mathrm{Classroom}$ Procedures}

The subjects of this study were students in a one-year United States history class at Dwight Township High School. Dwight is located in Illinois approximately $85 \mathrm{miles}$ south of Chicago and $55 \mathrm{miles}$ north of Bloomington and has had a school population of 300 to 350 students.

A control group of twenty United States history students received a treatment consisting of students reading and analyzing historians' interpretations on the Cold War. An experimental group of nineteen United States history students received a treatment consisting of the procedures proposed by McGill. Determination of control and experimental groups was decided by a flip of a coin. None of the control and experimental group students were regular members of my own classes. Instead, all studentsubjects were class members of a fellow instructor at Dwight High School and were enrolled as a requirement for the junior year of school. Prior to the students' receiving their respective treatments, the student-subjects had been using two textbooks: The American Dream and America at War: Wor id War I and World War I1.

Control and experimental group materials were created by this writer. Control group materials included edited readings that encompassed cold War historiography relative to Truman's decision to use the atomic bomb and the decision's impact on Soviet-American relations. ${ }^{9}$ Historiographic materials included works from orthodox, realist, and New Left schools of interpretation. Experimental group materials included brief lessons on primary and secondary sources, documentary materials relative to Truman's decision to drop the A-bomb, and interpretive readings dealing with Truman's decision. Primary materials for the experimental group were taken from a variety of sources that included memoirs, documents from Foreign Relations of the United States, Defense Department studies, letters, articles by contemporaries, and sources from the Truman Library in Independence, Missouri. The primary materials were organized under four headings: "Truman Explains How He Decided to Use the A-Bomb"; "The Japanese Make 'Peace' Initiatives"; "Truman's Contemporaries Explain Why the Atomic Bomb Was Used Against Japan"; and "New Evidence Discovered at Truman Library."

Students did not receive all four segements of materials at one time. Instead, the segments were presented on consecutive days in the order indicated above. Finally, experimental group materials al so included historiographic readings that represented divergent historical interpretations from the three schools of thought.

A pretest and post-test consisting of twenty-eight statements were given to both the control and experimental groups. These twenty-eight statements were organized into two categories. In Category. I fourteen items required students to react to statements that described what history is. The fourteen items in Category II required students to react to statements that described what historians do. The pretest and post-test were similar except that the order of the questions was varied to negate memory. This was done also in order not to orchestrate a discernible pattern to the responses. Student responses to these twenty-eight questions were measured by means of a Likert Scale. Fourteen of the twenty-eight statements were constructed to elicit a positive answer. The other fourteen statements were worded to elicit a negative response. The range of scores was twenty-eight 
as a minimum score and 140 as a maximum score. Both the pretest and the post-test were designed with the response keyed to reflect an overall concept of history based on a consensus of philosophical works by such historians as R.G. Collingwood, James Harvey Robinson, Benedetto Croce, Carl Becker, Cushing Strout, Marc Bloch, G.J. Renier, Page Smith, E.H. Carr, J.H. Hexter, Jacques Barzun, Henry Graff, David Hackett Fischer, and Michae 1 Krause. 10 A mean of students' concept of history for both the pretest and post-test in the control and experimental groups was then compared to determine if one or both of the approaches had sufficiently altered the students' concept of history.

\section{Classroom Procedures}

During the first class session, the pretest was administered to both the control and experimental groups. This test took about fifteen minutes to complete. In the control group students were asked what they had previously discussed in class about World War II. For the introduction students saw a slide presentation on the atomic bomb. During the slide presentation, the instructor provided students with basic information such as Harry Truman becoming President after Franklin Roosevelt, the war with Germany concluding before the war with Japan, the size and power of atomic bombs, target sites for the atomic weapons, and discrepancies relative to the number of Japanese killed and injured following the destruction of Hiroshima and Nagasaki. Students reacted to several of the slides, asking questions to validate statistics and other information. Students were then assigned to read an introduction about Truman's decision to use the atomic bomb and reactions to this decision by three schools of interpretation among historians.

In the second class session, the control group students briefly discussed the various schools of interpretation now existing among historians. The instructor then used an overhead projector to describe the three interpretive schools in more detail. This description was presented to students in the form of charts. At the conclusion of the presentation, students were assigned to read the first interpretive selection from William Appleman Williams's The Tragedy of American Diplomacy.

When the control group and instructor met for a third class session, students discussed the Williams reading. Many students found the selection difficult to undersiand, and, therefore, it was necessary to provide them with information regarding Williams's view of the "Open Door" policy. Initially, few students were able to identify Williams as representing the radical school of thought. But through discussion, students were able to perceive more clearly that Williams was New Left. Moreover, students examined Williams's comments on how the United States was to blame for the Cold War, and, in particular, they discussed Williams's remarks that U.S. leaders had "internalized" the "Open Door" policy.

In preparation for the fourth class session, the instructor assigned control group students to read selections from Herbert Feis's The Atomic Bomb and the End of World War II, D.F. Fleming's The Cold War and Its Origins, $1977-1960$, and Lis7e A. Rose's Dubious Victory. For the fifth class session, students read selections from Gabriel Kolko's The Politics of War and David Horowitz's The Free World Colossus. To prepare for the sixth and final class session, students were to read Samuel El iot Morison's "Why Japan Surrendered," a section from Louis J. Halle's work, The Cold War as History, and Gar Alperovitz's Atomic Diplomacy: Hiroshima and Potsdam. 
Control group students appeared confused by the various readings. From anecdotal reactions, students seemed to "wonder what al1 the readings were about" and tended initially to pick out selections or viewpoints with which they agreed. At first, students found it difficult to match historians with the appropriate school of interpretation. The instructor had students refer to the charts describing Cold War historiography. By the sixth class session, students as a whole exhibited more confidence in determining historians' viewpoints and examples of orthodox, realist, and New Left interpretive works. In this last session, control group students evaluated the slide presentation and secondary readings and took the post-test on a concept of history.

In the experimental group, the instructor, after having students take the pretest, also asked students what they had discussed in previous classes about World War II. The instructor then informed the class that they were going to discuss how historians examine and interpret materials. At that point each of the students received a lesson package. The students and instructor read and then discussed how an historian is like a detective when doing research and also differentiated between primary and secondary sources. The instructor responded to questions. For instance, one student wanted to know if there was a difference between a biography and an autobiography, and the class identified the distinction between the two terms. Students then participated in an exercise designed to help students distinguish between primary and secondary sources.

The experimental group, during the third class session, examined the documents dealing with Truman's decision to use the atomic bomb. After reading the materials under the section "Truman Explains How He Decided to Use the A-Bomb," students identified the type of sources they were examining, wrote a thesis statement, and supported their hypotheses with evidence. Students then read aloud their thesis assertions to the class. There were some variations in their thesis statements.

During the fourth and fifth class sessions, the experimental group students continued to work with primary sources. In the fourth class session, they received materials entitled "The Japanese Make 'Peace' Initiatives." Students read the materials and were given an opportunity to restate their hypotheses. Several students altered their original thesis statements. The class and instructor then discussed the various hypotheses, which now included the American demand for unconditional surrender and a U.S. commitment to that policy. Anecdotal remarks indicated a recognition on the part of some students that differing hypotheses were obviously based on differing interpretations of the evidence. Students also received and read source materials under the heading "Truman's Contemporaries Explain Why the Atomic Bomb was Used Against Japan." They were invited to revise again their own individual hypothesis.

In the fifth class session, several experimental group students read aloud their third hypothesis and cited source material support for their thesis statements. Immediately after reading their thesis statements, students read the document section entitled "New Evidence Discovered at Truman Library" and wrote their fourth hypotheses. One student, while reading the "New Evidence" excerpts, asked if Truman aiready had planned to use the A-bomb prior to his July 18 letter. The instructor responded that the decision had been made at a June 18 meeting with Truman's advisors. Several students, as they had done in previous sessions, read aloud their fourth hypotheses and a discussion ensued as to whether or not a letter from Truman to his wife could be considered reliable. Thus, the class and 
instructor referred to the lesson on primary sources and reliability. At the conclusion of class, students were assigned to read excerpts from Samuel Eliot Morison's "Why Japan Surrendered," Gar Alperovitz's Atomic Diplomacy, and Louis J. Halle's The Cold War as History.

In the last experimental group class session, students briefly discussed the three assigned readings. Similar to the control group students, most experimental group students found the readings confusing. At this point it was necessary for the instructor to summarize the three interpretive views. Most students, it appeared, were able to accept that there were differences in the interpretations, and a few students could identify specific differences among the three historians. At the conclusion of the last class session, students in the experimental group took the posttest on a concept of history.

\section{Statistical Procedures and Findings}

The purpose of this investigation was to study experimentally the effect of historical interpretations (with and without students first becoming historians themselves) on a student's concept of history. The use of pre-existing groups presented certain problems, most notably that the control and experimental groups may have held initial differences and capabilities prior to the treatments implemented in the classroom. Since this research used intact groups, this investigator utilized analysis of covariance, a statistical technique compensating for group differences and increasing the precision of the statistical tests. 2 For this study, the pretest was used as a covariate in an analysis of covariance design to adjust the means in the two groups involved. Results of this testing process imply that there was a statistical difference in the dependent variable.

Pretest and post-test results for the control and experimental groups yielded quite different mean scores. The control group had a mean score of 90.550 on the pretest and a post-test mean score of 92.263. The experimental group's pretest mean score was 95.474 and post-test mean score was 108.667. The total mean score for the control and experimental groups on the post-test was 100.24. Data comparing control group responses to experimental group responses for every item showed there was a significant difference between the two intact groups of the pretest only for statement 15. On the post-test, however, there was a significant difference between the two groups on statements $1,2,3,7,8,9,10,11,14,17$, and 19. This statistical information reveals that the two pre-existing groups did not differ significantly on the pretest but that there was a significant difference between the two groups on the post-test.

Comparison of mean scores between control and experimental groups demonstrated that there was a significant improvement in the experimental group's concept of history. That is, they became cognizant, as professional historians do, of the complexities involved in historical interpretation. Moreover, an examination of student responses on the Likert Scale indicated that experimental group students reflected a more confident response (whether correct or incorrect) to the twenty-eight post-test statements than did the control group students. Control group students were hesitant to respond either "Strongly Agree" or "Strongly Disagree," while experimental group students exhibited few inhibitions when responding to the twenty-eight post-test items. Furthermore, McGill's thesis--that students who, as it were, do not become historians before reading historians' writings will perceive history as mere argument rather than interpretation--appears to be 
valid. Item 8, which specifically dealt with McGill's thesis, showed a significant difference between the two groups on the post-test only. 0ther items also showed a significant difference in the experimental group's concept of what history is (Category I statements) and what historians do (Category II statements). Category I items 1,2, 3, 8, 10, and 19 indicated a significant difference on the post-test for the experimental group. Items 7, 11, and 14, which were included in Category II statements, al so showed a significant difference for the experimental group students compared to the control group.

Based on the above data, it may be safe to draw two conclusions: (1) students who became historians before reading diverse historians' writings were more likely to perceive history as interpretation rather than mere argument, and (2) students who, through a simulated experience, became historians before reading diverse historians' writings were less likely to see history merely as an accumulation of facts with the past never changing. Instead, they came to appreciate more fully the concepts that revisionism is natura 1, that historical revisionism is natural, and that historical views of the past do change because of new evidence, changing outlooks, and the perspective of time.

\section{Conclusions}

This research project has pointed out the importance of adequately preparing students taking history as a required course in their high school curriculum so that they might come to grasp some of the complex components of revisionism as a significant aspect of historical interpretation. Cold War historiography, especially focusing upon the New Left school of interpretation, provided an excellent vehicle due to its marked disagreement with both the orthodox and consensus schools. Students not only studied history as a subject, but by becoming participants in the use of historical me thodology were introduced to historiographical facts usually ignored at the secondary level.

Replication of this experiment should be carried on at both lower levels, that is elementary and junior high school, and at a higher level such as the freshman college level. Future research al so could measure the impact of the McGill procedure on student knowledge of history. Future research could include as well studies relative to the long-term effects of students understanding the underlying concepts of history. Some questions researchers may wish to consider are: (1) Do students exposed to the McGill stimulated process retain their understanding of concepts of history over long periods of time? (2) Is one student-simulated experience adequate for most students? or (3) Should student-simulated experiences be interspersed throughout an academic year or, for that matter, a student's academic life? Care must be taken not to utilize fields of history that are obscure, thus being too far removed from the historical background of the students, and the treatment must be adapted to the educational level of the students to be involved. Leo J. Alilunas has noted that in comprehending history "a mature understanding comes with maturity." 13 Similarly, Roy Hallam has cautioned, "If the material is too advanced for the children they' will either assimilate it without understanding, or will reject it with possible damage to their whole attitude to the subject." 4 Moreover, G.R. Elton has warned that students may become bored (especially when under the age of fifteen) with excessive and overly difficult attempts to help students understand what "history is really about." 15 
Such admonitions to teachers of history are well taken, but on the other hand instructors should not presume that the intricacies of historiography, if the materials and pedagogical techniques are commensurate with the age level of the students, are too complicated to be delved into. Teachers of history must be committed to an optimistic expectation that nonmajor history students can and should be exposed to the nature of the discipline and the process of thinking historically. ${ }^{16}$ Research indicates that even a considerable number of adult Americans, akin to their student counterparts, lack the ability to apply the principles of historicism to contemporary problems. 1

In contemporary times, when young people of eighteen are given the right to vote, it is imperative that they have the methodological skills, which insight into historiography imparts, to discern critically between subjective bias and scholarly objectivity. They must al so be able to detect the imposition of ideology into interpretive schemes lest they fall prey to propagandistic distortions of history. 8 Thus students who study history as a subject at all educational levels should be subjected, in some degree, to the use of primary sources and the inferential thinking involved in interpreting the factual data. Jerome S. Bruner has reminded us "that intellectual activity anywhere is the same, whether at the frontier of knowledge or in a third-grade classroom... The difference is in degree, not in kind." 19

It might be concluded that whenever history is taught, historiography should al so be introduced at an appropriate level of comprehension. The historical method thus acquired will not only contribute to students' better understanding of the factual side of history, but will teach them a methog of thinking that will continue long after specific facts are forgotten. 20 Students, at whatever level of education, who are captives of a textbook or a few history books from the library without any knowledge of historical revisionism are ill-equipped to benefit from their new-found knowledge. In fact, they may be ill served by their ignorance of the philosophic and ideological ramifications of the various schools of interpretation. It is the purpose of this study to promote more experimentation so that new strategies for pedagogical improvement may be developed. In summary, paraphrasing Charles Beard, "every person is his [or her] own historian." If this be so, it is incumbent upon those entrusted to teach history to insure a sound basis for that expectation.

\section{APPENDIX}

PRETEST/POST-TEST ON A CONCEPT OF HISTORY

Name Date

Year in School

Directions: Please respond Strongly Agree, Agree, Undecided, Disagree, or Strongly Disagree to the following statements.

1. Historical facts speak for themselves.

2. Historical views of the past do not change.

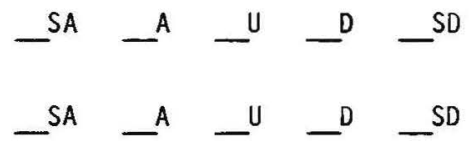


3. In the eyes of the historian, the past is constantly changing.

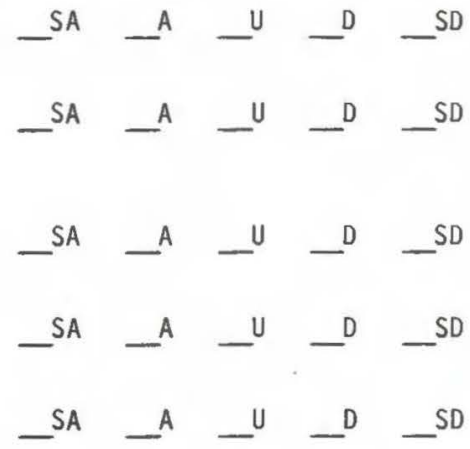

7. Historians continue to write about the past in order to explore alternative explanations.

8. History is an argument about the past. The reason is because historians have different opinions not because historians give evidence different meaning.

9. History is the interpretation of the available evidence of the past.

10. History is the description of the past as it actually was.

11. Each generation of historians edits and assembles evidence differently to explain the past.

12. The use of evidence is influenced by historians' previous experiences and beliefs.

13. The main task in reading history is not to understand the author's conclusions but to get the facts.
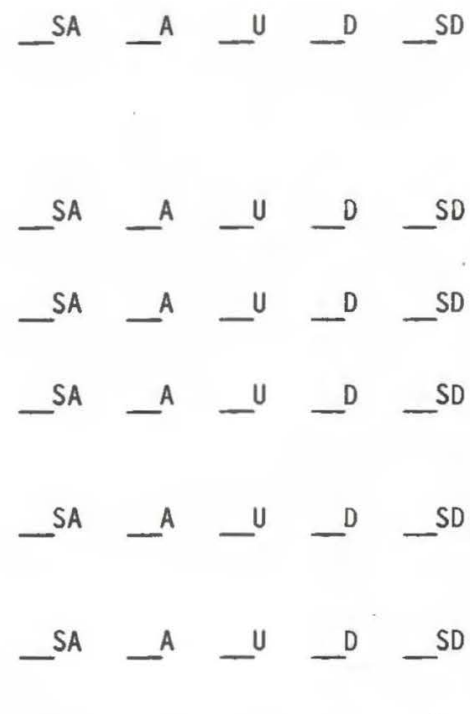

14. Historians should explain and interpret the facts.

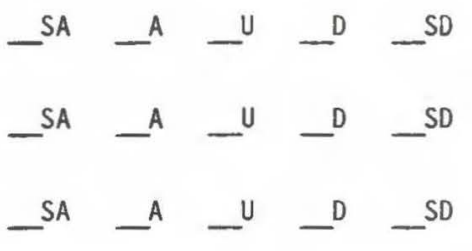
in the past.

17. Facts are what is recorded and constructed by the people who observe it.

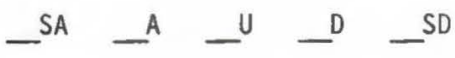

18. When I read a history book, I expect to read one person's explanation of the past.

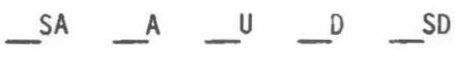


19. The writing of history is an accumulation of facts.

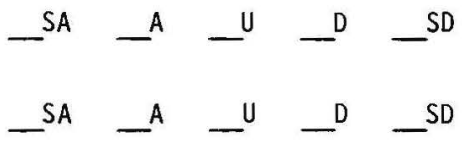

20. Historians can really tell us very little about the past because historians don't agree.

21. Historians are objective and let the facts speak for themselves.

22. History should be a study of the facts and not explanations of the past.

23. Eyewitnesses and participants record facts based on their past experiences.

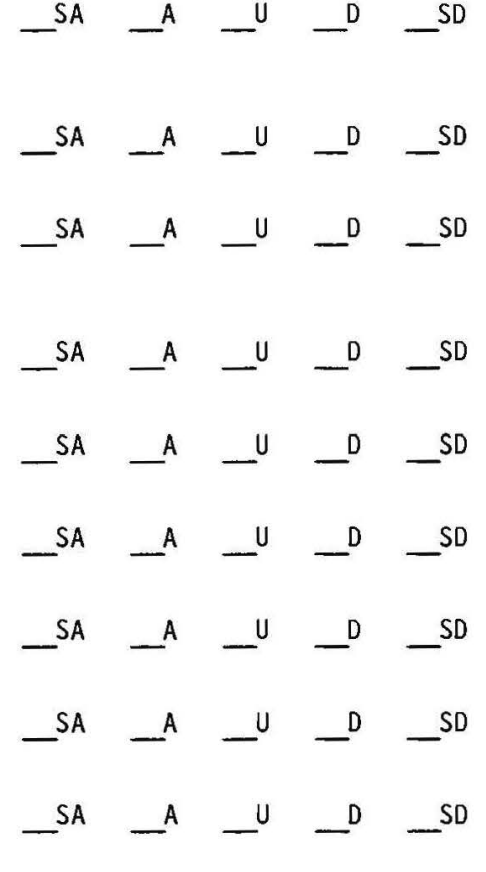

28. History is someone's explanation about the past.

24. Historians try to be objective about the past.

25. Historians try to increase humankind's knowledge of the past.

26. One person's opinion of the past is as good as another's.

27. Historians should be responsible to write the truth.

$$
\text { about the past. }
$$

\section{NOTES}

${ }^{1}$ For a discussion of the fact-oriented and interpretation-oriented views of history, see Alan B. Brownsword, "What's Wrong With the Teaching of History?" in Readings on Historical Method, ed. by Eric Russe 11 Lacy (New York: MSS Educational PubTishing Company, Inc., 1969), 97-105.

${ }^{2}$ For an excellent analysis of how historians can respond to the mass of knowledge, see E.A. Reitan, "The 'Knowledge Explosion' and the Academic Man," in Readings on Historical Method, 35-42.

${ }^{3}$ For a discussion of the se four categories, see Alan W. Brownsword, "Doing History: A Skills Approach," The History Teacher, 6 (1973), 251-266.

${ }^{4}$ Paul Cappuzze 110 and Mark Schlesinger, Recent Trends in History Curricula and Pedagogy (CUE Project) (Bowling Green, oH: BowTing Green State University, 1976), 7 .

${ }^{5}$ Mark M. Krug, "Primary Sources in Teaching History," The History Teacher, 3 (1970), 41-49; Thomas J. Kerr, "Developing Perception: The Use of New Interpretation in American History," The Social Studies, 62 (1971), 106-113; David C. Lukowitz, "Students as Apprentice Historians," Teaching History, 3 (1978), 14-19; W. Wayne Smith, "Involving Students in the Historical Process An Analysis of Jacksonian Politics," Teaching History, 3 
(1978), 20-22; Samuel J. Walker, "Teaching the Method of History: A Documentary Exercise," The History Teacher, 11 (1978), 471-482; Thomas Ladenburg, "Strategies for Teaching America Since 1945"," Teaching History, 7 (1982), 67-72; Lee A. Gladwin, "Why Can't Students Think More Like Historians?" Teaching History, 7 (1982), 78-85; and James J. Lorence, "The Critical Analysis of Documentary Evidence: Basic Skills in the History Classroom," Teaching History, 8 (1983), 77-84.

${ }^{6}$ See, for instance, Page Smith. The Historian and History (New York: Alfred A. Knopf, 1966); Lester D. Stephens, Probing the Past (Boston: Allyn and Bacon, Inc., 1974); and Carl N. Degler, "Remaking American History," The Journal of American History, 67 (1980), 7-25.

7William J. MCGill, "History as Interpretation and as Argument," Improving Col lege and University Teaching, 21 (1973), 115-116.

${ }^{8}$ Lew Smith, The American Dream (Glenview, IL: Scott, Foresman and Company, 1977), and Douglas Wait tley, America at War: World War I and Wor ld War II (Encino, CA: Glencoe Publishing Co.s Inc.s 1980).

${ }^{9}$ In an examination of six American high school history textbooks, Martin F. Herz wrote that sometimes inquiry texts, which stress readings, admonish "against bias" but then provide the readers with "a rather unbalanced diet of documentary readings." There is a false feeling of selfconfidence that the inquiry approach is less one-sided than the traditional, narrative method of instruction. Herz cautions that "with the inquiry approach the reader might not notice, because of the seeming diversity of the material, that the selected readings were entirely on one side of an issue." The selections for this package of materials provided a relatively wide-ranging presentation by the three interpretive schools. For Herz's assessment of high school history textbooks, see Martin F. Herz, How the Cold War is Taught (Washington, D.C.: Ethics and Public Policy Center, 1978, 76 .

10 James Harvey Robinson. The New History (New York: The Macmi11an Company, 1912); R.G. Col1 ingwood, The Idea of History (New York: Oxford University Press, 1980); Benedetto Croce, History, trans. Sy 1 via Sprigge (New York: W.W. Norton \& Company, Inc., 1941); Cushing Strout, The Pragmatic Revolt in American History: Carl Becker and Charles Beard (New

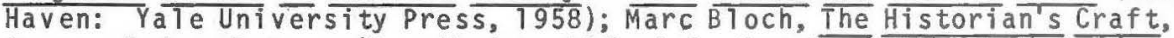
trans. Peter Putnam (New York: Alfred A. Knopf, 1963); G.J. Renier, History: Its Purpose and Method (London: George Allen \& Unwin Ltd., 1961); Page Smith, The Historian and History (New York: Alfred A. Knopf, 1964); Edward Hallett Carr, What is History? (New York: Vintage Books, 1961); J.H. Hexter, Doing History (B 100 mington, IN: Indiana University Press, 1975); Carl Becker, Everyman His Own Historian (New York: Appleton-Century-Crofts, Inc., 1935); Jacques Barzun and Henry F. Graff, The Modern Researcher (Chicago: Harcourt Brace Jovanovich, Inc., 1977); Michae Kraus, A History of American History (New York: Farrar \& Rinehart, Inc., 1937); Michael Kraus, The Writing of American History (Norman, OK: University of Oklahoma

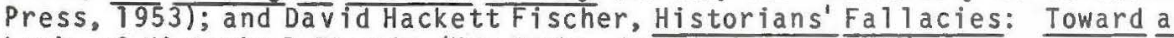
Logic of Historical Thought (New York: Harper \& Row, T970).

${ }^{11}$ This writer modeled several of the exercises on primary and secondary sources after Conal Furay and Michael J. Salevouris, History: A Workbook of Skill Development (New York: New Viewpoints, 1979). 
${ }^{12}$ W. James Popham, Educational Statistics: Use and Interpretation (New York: Harper \& Row Pubitishers, 1967 $\longdiv { , 2 2 7 - 2 3 1 . }$

13 Leo J. Alilunas, "The Problem of Children's Historical Mindedness," in The Teaching of History, edited by Joseph S. Roucek (New York: Phi Tosophical Library, 1967), 791.

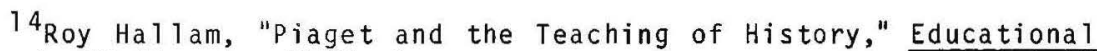
Research, 12 (November 1969), 6.

15 G.R. Elton, "What Sort of History Should We Teach," in Martin Ballard (ed.), New Movements in the Study and Teaching of History (Bloomington, IN: Indiana University Press, 1970), 221-222.

${ }^{16}$ E.A. Reitan, "Problems in Teaching the Introductory Survey Course in European History," in The Teaching of History, 196.

17 Martin E. Sleeper, "A Developmental Framework for History Education in Adolescence," School Review, 84 (1975), 105; and Michael. A. Zaccaria, "The Development of Historical Thinking: Implications for the Teaching of History," The History Teacher, 11 (1978), 336.

${ }^{18}$ This aspect al so may be of particular importance relative to the present nuclear deterrence and nuclear freeze controversy. Numerous interest groups have provided public positions regarding this issue. For an overview of interest groups, see Resources for Strengthening International Studies in Schools: A Directory of organizations, Social studies Development center, Bloomington, IN: Indiana University.

19 Jerome S. Bruner, The Process of Education (Cambridge: Harvard University Press, 1969), 31 .

${ }^{20}$ The teaching of the cold war to enhance a method of thinking is specifically encouraged in articles by Thomas J. Kerr, "Developing Perception: The Use of New Interpretation in American History," The Social Studies, 62 (1971), 106-113, and Fraser Harbutt, "A Course on the History of U.S.-Soviet Relations," Perspectives, 22 (1984), 23-24. Harbutt's article provides a detailed i ist of readings covering the gamut of cold War historiography and implementation of these readings into a well-structured course outline. 